\title{
Sosio-Eco- Religio -Culture dalam Penyelamatan Krisis Lingkungan Hidup
}

\section{Husni Thamrin}

\author{
Program Studi Ekonomi Syariah Program Pascasarjana Universitas Islam Negeri Sultan Syariif Kasim Riau \\ Jl KH Ahmad Danlan No 94 Pekanbaru ,Riau Indonesia \\ husni2017husni@gmail.com
}

\begin{abstract}
One of the ironies of the development of human civilization is the development and modernization is intended to improve the quality of human life, but it is more often the presence of people become victims of development and modernization. More ironically, land and indigenous peoples are victims of an anthropocentric perspective and government policies that do not favor the local community.This is attributable to several factors: First, the ideology of developmentalism does not incorporate local wisdom, especially regarding indigenous land policy and management and wealth preservation socio-eco-religio-cultural as an integral part of all development programs. In the ideology of developmentalism traditionalism is the opposite of modernization so that all that is traditional, including indigenous lands rich culture and local wisdom considered adaptive in the times. Second, misperceptions people who think the indigenous people of Malays as a destroyer of the environment that must be removed or relocated in order to save the environment. Yet, precisely Malays indigenous peoples are the guardians of the environment from the invasion and destruction by outside communities, immigrant communities. Third, the nature only in terms of economic value, so that the release of the entire ecological value, the local political, social, cultural, spiritual and moral associated with customary land and the lives of indigenous peoples in the surrounding. Exploit indigenous lands and natural resources for the purpose of economic development and seen off as not have negative consequences for the existence of the indigenous population. Fourth, modernization and progress of civilization seen and measured primarily by the quality of the physical-economic-capitalistic. To improve the socio-economic level of local communities, especially the Malays must be returned to the ethical values of indigenous peoples. Socio-economic rights of indigenous peoples should be recognized and guaranteed by the government. There must be political commitment at global and national levels to protect the land rights of indigenous peoples and all the wisdom of socioeconomic Through paradigm approach socio-eco-religo culture is to save the existence of indigenous land as a factor supporting economic activity and all the wealth and wisdom of traditional, it can also be save the ecological crisis is mainly caused by faulty worldview that policy makers anthropocentric-capitalistic paradigm should be changed to sosio-eco-religio culture perspective.
\end{abstract}

Key words: Anthropocentric Capitalistic, Socio- eco-religio -culture, and Local Wisdom

Kearifan lokal masyarakat adat Melayu mengalami erosi, atau kritis sebagian terdegradasi yang disebabkan beberapa faktor. terjadi proses desakralisasi alam oleh invasi dan dominasi kegiatan ekonomi kapitalistik yang antroposentrik-kapitalistik dan teknologi modern. Alam yang dipahami sebagai sakral oleh masyarakat adat Melayu dan menyimpan sejuta nilai nilai kearifan lokal yang telah lama mengakar dalam kehidupan masyarakat bisa dijelaskan dengan menggunakan akal budi, sehingga membangkitkan sikap kagum penuh rasa hormat, sakralitas dan misterinya telah dieleminir dalam paradigma antroposentrikkapitalistik dan teknologi modern. Dalam paradigma antroposentrik yang positivistikkapitalistik, alam dipahami sebagai sekadar fakta yang profan tanpa getaran sakral-magisreligius, tanpa nilai dan muatan moral sama sekali. Alam direduksi sekadar sebagai obyek dan fakta yang bisa dipilah-pilah, dianalisis dan dijelaskan secara ilmiah-rasional. Fenomena 
alam yang dipahami sebagai misteri ternyata dalam perspektif ilmu pengetahuan modern hanya problem yang bisa dijelaskan secara ilmiah dan rasional: bahwa ternyata alam dan semua kehidupan serta benda di dalamnya terdiri dari berbagai unsur kimia, fisika, dan biologi yang bisa diuraikan. Interaksi berbagai unsur kimia, fisika, dan biologi tersebutlah yang menimbulkan berbagai fenomena alam'yang menimbulkan rasa kagum, takut, dan takjub. Ternyata semua hal itu sebagai sebuah fenomena alam yang rasional-ilmiah yang berjalan secara posistivistik.

Paradigma antroposentrik telah menjauhkan manusia dari alam, sekaligus menyebabkan sikap eksploitatif dan tidak peduli terhadap alam. Dalam kaitan dengan itu, krisis ekologi dilihat pula sebagai disebabkan oleh cara pandang mekanistis-reduksionistis-dualistis dari ilmu pengetahuan Cartesian tersebut. Cara pandang yang antroposentris dikoreksi oleh etika bio-sentrisme dan ekosentrisme, khususnya Deep Ecology, untuk kembali melihat alam sebagai sebuah komunitas etis(Keraf, 2010).

Konsep soso-eco-religio-culture sesungguhnya sudah sejak awal mula dipraktikkan oleh masyarakat adat Melayu atau masyarakat-masyarakat tradisional di tempat lainnya.Cara pandang mengenai manusia sebagai bagian integral dari alam, serta perilaku penuh tanggung jawab, penuh sikap hormat dan peduli terhadap kelangsungan semua kehidupan di alam semesta, telah menjadi cara pandang dan perilaku berbagai masyarakat Melayu,

Sebagian kearifan lokal s Melayu dalam pemeliharaan lingkungan hidup di antaranya masih tetap bertahan di tengah hempasan arus pergeseran oleh desakan cara pandang antroposentrik. Ada pula yang sedang mengalami krisis karena desakan pengaruh modernisasi tersebut. Sementara yang lain, hanyut terkikis hilang ditelan modernisasi dan cara pandang yang antroposentrik.Untuk itu diperlukan solusi yang akurat untuk menjawab tantangan zaman yang semakin hari semakin mencemaskan kehidupan manusia sebagai akibat keserakahan umat manusia.

\section{BAHAN DAN METODE}

Penelitian ini menggunakan metode kualitatif grounded research, yang bertujuan untuk memahami keberadaan yang saling berhubungan antara berbagai gejala eksternal dan internal dalam kehidupan masyarakat adat di Propinsi Riau. Dalam kaitan antropologi lingkungan, studi ini menggunakan pendekatan struktural. Dalam pendekatan ini lingkungan dilihat dalam pengertian hubungan formal, yang mengungkap hubungan lingkungan hidup yang nyata antara individu dan kelompok. Pendekatan ini lebih jauh menekankan pada model-model pendeskripsian realitas lingkungan sebagai keadaan yang koheren, menekankan keseimbangan, sedangkan dalam realitasnya tidak memiliki karakteristik koherensi yang menyeluruh.

Data pokok yang dikumpulkan dalam penelitian ini terpusat pada fenomena-fenomena yang berkaitan langsung khususnya dengan kearifan lokal Melayu , yang berkaitan dengan aspek kehidupan sosial, lingkungan dan ekonomi dengan kontek eco-culture. Data pokok yang diperlukan tersebut dipilih dan dibatasi berdasarkan relevansi dengan pertanyaan dasar dalam rencana penelitian, yang keseluruhannya ditempatkan dalam rangka analisis teori antropologi lingkungan. Dalam pada itu data tentang kondisi lingkungan hidup dan unsur-unsur kebudayaan lainnya yang bersifat umum tetap dikumpulkan selama penelitian lapangan dan penelitian kepustakaan berlangsung. Hal ini dilakukan untuk mendapatkan hasil analisis data pokok ke dalam kesatuan kebudayaan orang Melayu secara holistik. Kegiatan analisis data dimulai dari klasifikasi, kategorisasi, dan interpretasi, sampai pada pembahasan. Pengolahan data atau analisis deskriptif (descriptive analysis) mengandung pengertian sebagai usaha untuk menyederhanakan dan sekaligus menjelaskan bagian dari keseluruhan data melalui langkahlangkah klasifikasi dan kategorisasi sehingga tersusun suatu rangkaian deskripsi yang sistematik dan akurat.

Proses pengklasifikasian dan pengkategorisasian data dilakukan sejak berada di lapangan, bersamaan dengan proses pengumpulan data dan dilanjutkan secara lebih terperinci dan sistimatis setelah keseluruhan 
data terkumpul. Klasifikasi dan kategorisasi data dilakukan secara bagian perbagian, akan tetapi tetap mempertahankan posisi kebudayaan Melayu sebagai satu kesatuan yang utuh. Dalam proses kategorisasi data tersebut terkandung usaha interpretasi kualitatif yang dilakukan secara induktif berdasarkan pada pendekatan emik (emic approach). Dalam kaitan ini langkah pendekatan etik ditempatkan dalam kerangka teori antropologi lingkungan untuk melihat arti penting tanah adat sebagai sumber kehidupan dan pelestarian lingkungan.

Dalam penelitian ini data yang dianalisis terdiri dari data primer dan sekunder. Analisis fokus penelitian berkaitan dengan identifikasi masalah dan tujuan penelitian yang dibagi menjadi fokus dan sub fokus penelitian sebagai berikut :

Fokus dan Sub Fokus Analisis Penelitian

\begin{tabular}{|c|c|c|c|c|}
\hline No & Tujuan & Focus & Sub-Focus & Data \\
\hline \multirow[t]{2}{*}{1} & $\begin{array}{l}\text { Menganalisis Status Lingkungan } \\
\text { Hidup }\end{array}$ & 1.Iklim & $\begin{array}{l}\text { 1. Kebakaran Hutan } \\
\text { 1. Pencemaran } \\
\text { 2. Udara } \\
\text { 3. Penyakit } \\
\text { 4. Asap } \\
\text { 5. Perubahan Iklim }\end{array}$ & Kualitatif \\
\hline & & $\begin{array}{l}\text { 2.Hidrologi } \\
\text { 3.Hutan dan Tanah }\end{array}$ & $\begin{array}{l}\text { 1. Kualitas Air } \\
\text { 2. Rawa dan Danau } \\
\text { 3. Dagradasi Sungai } \\
\text { 4. Banjir } \\
\text { 1. Hutan -tanah adat } \\
\text { 2. Kasawan Budidaya } \\
\text { 3. Flora dan fauna } \\
\text { 4. Dagdradasi Ekosistem }\end{array}$ & Kualitatif \\
\hline 2. & $\begin{array}{l}\text { Menganalisis keberadaan } \\
\text { kearifan Lokal Pelestarian } \\
\text { Lingkungan }\end{array}$ & 1.Kawasan Lokal & $\begin{array}{l}\text { 1. Rokan Hilir } \\
\text { 2. Siak } \\
\text { 3. Kuantan Singingi }\end{array}$ & Kualitatif \\
\hline \multirow{6}{*}{3} & & 2. Jati diri Manusia & $\begin{array}{l}\text { 1. Sosio- Historis } \\
\text { 2. Sosio-Budaya } \\
\text { 3. Tanah Adat } \\
\text { 4. Nilai Etika Melayu }\end{array}$ & Kualitatif \\
\hline & & 3. Pranata adat & $\begin{array}{l}\text { 1. Peran Tokoh Adat } \\
\text { 2. Struktur Adat. } \\
\text { 3. Nilai Adat }\end{array}$ & Kualitatif \\
\hline & $\begin{array}{l}\text { Menganalisis Fungsi lokal } \\
\text { Wisdom }\end{array}$ & 1. Kultural & $\begin{array}{l}\text { 1. Identitas } \\
\text { 2. Marwah } \\
\text { 3. Kekerabatan }\end{array}$ & Kualitatif \\
\hline & & 2.Cosmologis & $\begin{array}{l}\text { 1. Magis } \\
\text { 2. Mitos } \\
\text { 3. Pantang larang. }\end{array}$ & Kualitatif \\
\hline & & 3.Sosial Ekonomis & $\begin{array}{l}\text { 1. Berladang } \\
\text { 2. Berkebun. } \\
\text { 3. Nelayan. } \\
\text { 4. Pancung Alas } \\
\text { 5. Tapak Lawang }\end{array}$ & Kualitatif \\
\hline & & 4.Ekologis & $\begin{array}{l}\text { 1. Hutan Tanah Adat } \\
\text { 2. Sungai, Danau, laut dan Rawa. } \\
\text { 3. Flora dan Fauna }\end{array}$ & Kualitatif \\
\hline
\end{tabular}




\section{HASIL}

Dalam masyarakat Melayu ,Kearifan lokal dalam perspektif sosio-eco-religio-culture dipandang sebagai identitas kultural (cultural identity). Identifikasi diri (self identification) seseorang, sebagai orang yang menganut local wisdom dihubungkan dengan suku dan negerinya juga dikaitkan dengan tanah. Sesuai dengan pepatah adat kalau terpelihara hutan dan tanah banyak manfaat besar faedah, bila tersesak panjanglah langkah, bila sempit lari ke tanah; apabila rusak hutan dan tanah sekitar, sempit tidak dapat berlegar, goyah tidak dapat bersandar, panas tidak dapat mengekas, hujan tidak dapat berjalan, teduh tidak dapat berkayuh, air kering kerontang, musnahlah alam dan manusia. Tanah sebagai sumber kehidupan, sumber air, kita berasal dari tanah, memelihara tanah dan kembali ketanah. (Wawancara dengan Hasan Basri, di Bangko Pusako, tanggal 27 Agustus 2018)

Orang Melayu yang berladang di daerah rawa-rawa mempunyai kebiasaan menanam rumbia dan rumbai di tepi ladang mereka. Tanaman rumbia telah membuat ladang mereka mendapat cadangan simpanan air ketika tiba musim kemarau karena tanaman ini dapat menyimpan air. Sementara itu, rumbia dapat di jadikan barang anyaman, di antaranya dibuat jadi ago untuk alat pengangkut padi. Pohonpohon rumbia lebih banyak lagi kegunaannya. Daun rumbia dijadikan atap, sedangkan sagunya bisa diolah menjadi bahan makanan kalau ladang mereka tidak selamat.

Tradisi menjaga kelestarian tumbuhtumbuhan misalnya dapat dilihat pada tradisi menjaga pohon durian yang terdapat di perkampungan orang Melayu . Apalagi di kampung daerah aliran sungai sebagai tempat yang disukai durian. Jika durian sudah berbuah, orang Melayu punya tradisi mengambil buah durian dengan tidak dipanjat, tetapi dibiarkan jatuh buah yang sudah masak. Jika ada orang (terutama anak-anak) hendak memanjat, akan diberi peringatan bahwa durian yang dipanjat tidak akan berbuah lagi, malah batangnya akan mati.

Larangan yang berisi mitos perlu diadakan penelitian relatif mendalam terhadap kebenarannya. Namun yang penting, dengan larangan itu durian akan dibiarkan masak, tidak dipanjat yang akan menyebabkan durian muda tidak akan diambil (rusak). Tradisi ini penting untuk kelestarian pohon durian yang masak mempunyai biji yang siap di tanam. Tradisi lain untuk menjaga kelestarian lingkungan seperti menjaga pohon sialang, pohon yang menjadi tempat bersarang lebah. Kayu sialang ada yang berupa cempedak air (tumbuh di tebing sungai), kayu ara, kempas, suluh batang dan sebagainya. Mengambil madu lebah tidak boleh sembarangan. Lebah tidak boleh dibinasakan untuk mengambil madunya. Untuk kepentingan ini diadakan suatu upacara yang dipimpin oleh seorang dukun dan perangkatnya yang di beri tugas mengambil madu lebah. Dia dapat mengambil madu lebah dengan aman dengan mendekatkan asap tunam kepada lebah. Ketika lebah kena oleh asap, maka lebah menghindar. Dengan demikian madunya mudah diambil.

Tentu atas kesadaran betapa besarnya manfaat lebah sialang, maka kayu sialang tempat lebah berkembang biak tidak boleh ditebang begitu saja menurut adat orang Melayu. Siapa yang kedapatan menebang pohon sialang dengan alasan yang tidak kuat, akan kena denda dengan menyerahkan kain putih sepanjang kayu sialang yang telah ditebangnya.

Dalam pandangan orang Melayu hidup hendaklah dilandasi oleh agama, adat dan resam yang baik. Adat bertumpu pada agama, bagaikan tiang berpijak pada sendirinya. Jika tidak begitu, hidup akan binasa, ibarat tiang tanpa sendi, akan lapuk dimakan karat. Agama memberi panduan hidup dan mati, adat mengawal agar hidup mulia sedangkan resam (tradisi) membuat hubungan harmonis dengan alam. Maka, orang yang beriman, beradat dan beresam yang baik, akan memelihara hubungan dengan Tuhan, manusia dan alam sebab tidak ada satupun yang diciptakan Tuhan dengan siasia. Inilah jalan manusia menuju menjadi makhluk mulia, sebagaimana tertulis dalam kata bersajak berikut ini.

"Adat hidup memegang adat. Tahu menjaga laut dan selat. Tahu menjaga rimba yang lebat. Tahu menjaga tanah ulayat. Tahu menjaga semut dan ulat. Tahu menjaga togok dan belat. Tahu menebas memegang adat. Tahu menebang memegang amanat. Tahu beladang menurut undang. Tahu berkebun mengikut kanun. Beramu tidak merusak kayu. Berotan 
tidak merusak hutan. Bergetah tidak merusak rimba. Berumah tidak merusak tanah. Berkebun tidak merusak dusun.Berkampung tidakmerusak gunung. Berladang tidak merusak pedang. Adat hidup memegang amanah. Tahu menjaga hutan dan tanah. Tahu menjaga bukit dan lembah. Berladang tidak merusak tanah. Berkebun tidak merusak rimba"(Wawancara dengan Arsyad, 77 tahun, tokoh Adat Pelalawan )

Manusia harus menyadari dia berada di muka bumi sebagai khalifah, yakni seorang yang bertindak sebagai pemelihara segala kekayaan Tuhan. Dia muncul bukan untuk mengharu-biru, demi ambisi dan nafsu serakahnya tetapi bertindak bijaksana melestarikan hutan tanah, air, flora dan fauna, sehingga mendapat sebesar-besar manfaat dari situ. Ini dapat dilihat dalam penuturan informan di lapangan sebagai berikut :

“Kalau terpelihara hutan tanah. Banyak manfaat besar faedah. Bila tersesak panjanglah langkah. Bila sempit lari ketanah. Kalau terpelihara alam lingkungan. Banyak manfaat dapat dirasakan. Ada kayu untuk beramu. Ada tumbuhan untuk ramuan. Ada hewan untuk buruan. Ada getah membawa faedah. Ada buah membawa berkah. Ada rotan penambah penghasilan. Kalau terpelihara alam sekitar. Manfaatnya banyak, faedahnya besar. Di situ dapat tempat bersandar. Di situ dapat tempat berlegar. Di situ dapat membuang lapar. Di situ dapat didengar. Di situ kecil menjadi besar. Di situ sempit menjadi lebar." (Wawancara dengan Penghulu Alju di Rantau Bais, Tanah Putih, 17 November 2017).

Ketika manusia tidak dikawal dengan agama, tidak dipandu dengan adat, dan tidak mempunyai tradisi yang baik, maka dia akan mendatangkan bencana. Namun kemudian, kerusakan itu akan berbalik mengancam manusia itu sendiri. Ini yang akan mempercepat kiamat dari sudut pandang budaya manusia, meskipun kiamat yang sebenarnya adalah rahasia Allah semata. Keadaan ini sudah dibidal oleh orang patut Melayu dalam rangkaian kata yang puitis.

“Apabila rusak alam sekitar. Sempit tidak dapat berlegar. Goyah tidak dapat bersandar. Panas tidak dapat mengekas. Hujan tidak dapat berjalan. Teduh tidak dapat berkayuh. Apabila alam sudah binasa .Bala turun celaka tiba. Hidup melarat terlunta-lunta. Pergi ke laut malang menimpa. Pergi ke darat miskin dan papa. Apabila alam menjadi rusak. Turun temurun hidupkan kemak. Pergi ke laut di telan ombak. Pergi ke darat kepala tersundak. Hidup susah dadapun sesak. Periuk terjerang nasi tak masak. Apabila alam menjadi punah. Hidup dan mati takkan semenggah. Siang dan malam ditimpa musibah. Pikiran kusut hati gelebah. Apabila rusak alam lingkungan. Di situlah puncak segala kemalangan. Musibah datang berganti-gantian. Celaka melanda tak berkesudahan. Hidup sengsara binasalah badan. Cacat dan cela jadi langganan. Hidup dan mati jadi sesalan. Apabila alam porak poranda, di situ tumbuh silang sengketa. Aib datang malu menimpa" (Effendi, 2004).

Fungsi sosio-eco-religio culture kosmis orang Melayu tradisi dalam pemeliharaan lingkungan bersumber dari dukun, bomo, pawang, kemantan, guru silat, tokoh adat, para raja, dan ulama (memelihara umat dengan ajaran dan nilai Islam). Mereka mempunyai peranan masing-masing dalam masalah melestarikan lingkungan hidup. Dari nilai dan ajaran Islam, orang Melayu mengetahui bahwa tiap manusia dikawal atau diawasi oleh malaikat. Dalam wawancara peneliti dengan dukun Melayu, di Pulau Rupat Bengkalis Manan (54 tahun) membuat analogi atau mitos bahwa tiap makhluk hidup berupa binatang liar dan burung dikawal oleh makhluk halus bernama sikodi, sejenis makhluk hidup yang tinggal di hutan belantara. Dari pandangan tradisional serupa ini, tidak ada warga yang berani semena-mena begitu saja mengambil apalagi merusak flora dan fauna. Jika mereka merasa memerlukannya, mereka meminta bantuan dan petunjuk para dukun sehingga merasa aman mengambilnya.

Untuk memperkuat perlindungan alam lingkungan itu sehingga flora, fauna, tanah dan laut tidak diperlakukan begitu saja oleh tangantangan jahil. Para dukun dan tetua Melayu masa silam membuat bermacam cerita mengenai binatang, burung, pohon, sungai dan laut. Benda apapun yang disentuh oleh makhluk halus bisa mempunyai kekuatan gaib sehingga disebut juga puaka (sacral). Informan Hasan (87 tahun, Dukun di cerenti, Kuantan Singingi ) mengatakan pada tempat tertentu yang memberi peluang untuk dihuni oleh makhluk halus, seperti sungai, tanjung, lubuk dan beting disebut 
keramat karena dipercaya dapat memberi petaka jika diperlakukan sesuka hati. Benda keramat seperti keris, tidak boleh disalahgunakan. Tempat-tempat sakral dan kuburan orang saleh disebut keramat sehingga tidak boleh dipakai untuk tempat mendirikan bangunan. Dengan demikian, barang dan kawasan tertentu ini mendapat keamanan dengan sendirinya sebab tak ada orang Melayu yang berani mengganggunya. Kepentingan warga masyarakat terhadap para dukun dalam masyarakat tradisonal cukup besar.

Rimba simpanan adalah hutan belantara yang sengaja di biarkan lestari begitu rupa. Oleh karena tidak boleh siapa saja menjadikannya tanah produksi seperi dijadikan kebun dan ladang, maka disebut juga hutan larangan. Hasil-hasilnya dalam kayu perumahan (bangunan) berbagai buah-buahan, rotan, binatang buruan, berjenis burung dan ikan. Hasil-hasil ini boleh diambil atas sepengetahuan lembaga adat atau seizin pemangku adat yakni Penghulu atau Datuk Adat. Para dukun meracik dan meramu tumbuhan obat-obatan untuk mengobati berbagai jenis penyakit sesuai dengan pengetahuan mereka tentang tumbuhan obat tersebut. Seorang dukun Ketah (73 tahun) mengidentifikasi jenis penyakit yang menyerang seseorang dan mencari tumbuhan obat yang sesuai untuk penyakit tersebut. Tumbuhan obatobatan ini dapat mereka temukan di sekitar kawasan hutan adat. Pengetahuan tentang ekosistem hutan sebagai dasar yang digunakan dalam menemukan tumbuhan obat-obatan tersebut. Misalnya suatu jenis tumbuhan obat yang hanya tumbuh di daerah-daerah tertentu saja.

Saat ini (2018) akibat pandangan dan kepentingan Antropocentrik-kapitalistik ,flora,fauna , danau,sungai laut dn belat sebagai tempat orng Melayu Mengantungkan hidup telah banyak yang hilang Hilangnya keanekaragaman hayati sebagai akibat dari Antropocentrik kapitalistik yang lebih mementingkan kesekahan ekonomi ,yakni paham positivistik, sebagai "agama masyarakat "modern, terjadi kehancuran dan kepunahan keanekaragaman hayati yang begitu kaya dalam masyarakat Melayu .Dampak timbal baliknya adalah, semakin punah keanekaragaman hayati itu semakin punah dan terkikis pula kearifan tradisional Melayu dengan segala nilainya, karena kearifan tradisional terkait erat dengan keanekaragaman hayati.Kearifan tradisional hanya mungkin dipertahankan kalau alam dan segala kekayaan di dalamnya masih tetap dipelihara. Ketika alam dengan segala kekayaannya terancam punah, punah pula seluruh kearifan tradisional tersebut.

Hilangnya sebagian besar hak-hak tanah adat masyarakat adat orang Melayu , termasuk hak untuk hidup dan bertahan sesuai dengan identitas dan keunikan tradisi budayanya serta hak untuk menentukan diri sendiri. Di tengah invasi dan dominasi masyarakat modern karena pengaruh antroposentrik, masyarakat adat yang berbeda tradisi budayanya dan kehilangan hak tanah adat. Ini terjadi baik karena kolonialisme dan imperialisme, maupun karena modernisasi Barat membawa dampak tersingkir dan punahnya masyarakat adat di seluruh dunia. Apa yang mereka kenal seumur hidup tidak mendapat tempat dalam kerangka hukum dan etika modern. Bersamaan dengan hilangnya hak-hak tanah adat masyarakat Melayu , hilang pula kearifan lokal mereka yang begitu menentukan cara beradanya masyarakat adat Melayu . Sebaliknya, dengan hilangnya tanah adat tersebut itu, maka terancam pula keberadaan kearifan lokal masyarakat Melayu

Salah satu ironi yang terjadi pada masyarakat Melayu adalah, kegiatan ekploitasi perminyakan, industri raksasa keertas dan penenaman masal kepalapa saewit yang semstinya membawa dapak positif bagi perkembangan perekonomian bagi Masyarakat Melayu Riau jestru yang terjadi sebaliknya justru masyarakat Melayu Riau menjadi korban dari ekploitasi perusahaan raksasa tersebut . Lebih ironis lagi, tanah dan masyarakat Rokan Hilir menjadi korban dari cara pandang antroposentrik kapitalistik .

\section{PEMBAHASAN}

Sosio-eko-relgio-culture adalah sustu pendekatan cara berfikir dan betindak secara eika lingkungan melihat aspek sosial ,fisik , agama dan budaya penyelematan lingkungan secaa holitik yang mendorong umat manusia untuk meninggalkan cara pandang yang antroposentris kapitalistik , , manusia sesungguhnya diajak untuk kembali ke kearifan loka . Dengan kata lain, etika lingkungan hidup 
orang Melayu adalah menghimbau dan mengajak manusia saat ini untuk kembali ke etika masyarakat adat Melayu secra holistik dan sentesisa adaptif dari nilai nilai sosial, agama ,budaya dan ekologis yang masih relevan dengan perkembangan zaman. Inti pandangan ini adalah kembali ke alam yang adaptif secatara holistik dalam tataran global, kembali ke jatidirinya sebagai manusia Melayu yang ekologis. Etika lingkungan hidup sesungguhnya menyadarkan orang Melayu untuk tidak terperangkap dan terbuai oleh cara pandang antroposentris untuk kembali menghayati cara pandang sosio-eco-religio-culture secara holistik.

Atas dasar itu, perlu meninjau kearifan atau pengetahuan masyarakat adat di berbagai kawasan tentang manusia, alam, dan hubungan manusia dengan alam. Tinjauan akan dipusatkan pada tiga hal. Pertama, cara pandang masyarakat adat Melayu tentang dirinya, alam dan hubungan antara manusia dan alam. Kedua, kekhasan pengetahuan tradisional yang dimiliki masyarakat adat Melayu sekaligus menentukan pola hidup dan perilaku masyarakat adatnya terhadap alam. Ketiga, hak-hak masyarakat adat Melayu yang perlu dilindungi, karena dengan melindungi hak-hak mereka, tidak saja eksistensi masyarakat adat ini dilindungi, tetapi juga etika mereka serta alam yang menjadi sasaran

Terjadi desakralisasi alam, yang membuat alam tidak lagi menarik untuk dihormati, disembah, dan dipelihara penuh takjub. Maka, manusia pun melihat dirinya begitu agung dan superior berhadapan dengan alam yang tidak berarti sama sekali. Oleh karena itu, sikap hormat, perilaku merawat, mencintai dan menjaga keharmonisan atau hubungan baik dengan alam menjadi tidak relevan dan tidak punya tempat lagi. "Desakralisasi(alam) terjadi melalui perubahan makna ruang (space). Ruang yang sakral, pusat segala makna dan kehidupan, sumber ekologis dari keberlangsungan hidup, diubah menjadi sekadar tempat (site), lokasi dalam pandangan antroposentrik. Padahal dalam pandangan orang Melayu hubungan manusia-alam-Allah adalah relasi metafisis religious yang sacral, banyak pantang larang dan petuah yang esensinya bersumber dari Al-Quran dapat dilihat relasi dengan alam dalam surat al-Baqarah (2): 164
Sesungguhnya dalam penciptaan langit dan bumi, silih bergantinya malam dan siang, bahtera yang berlayar di laut membawa apa yang berguna bagi manusia, dan apa yang Allah turunkan dari langit berupa air, lalu dengan air itu Dia hidupkan bumi sesudah mati (kering) nya dan Dia sebarkan di bumi itu segala jenis hewan, dan pengisaran angin dan awan yang dikendalikan antara langit dan bumi; Sungguh (terdapat) tanda-tanda (keesaan dan kebesaran Allah) bagi kaum yang memikirkan.

Regulasi hukum dan kebijakan hanya untuk kepentingan nilai ekonomis kapitalistik telah memarjinalkan nilai nilai kearifan lokal orang Melayu sebagai contoh kasus keberadaan Tanah Orang Melayu Rokan Hilir yang luas $8.881,59 \mathrm{~km}^{2}$ atau 888.159 hektar.Namun Keberadaan tanah orang adat di Rokan Hilir (20150 di daerah Bangko terdapat di perbatasan Lengadai-Bantaian Hilir seluas 500 Ha,di Bangko Pusako seluas 200 Ha. Tanah adat di Kubu terdapat di Teluk Nilap seluas 200 Ha. Jojol, Sei Panji-panji seluas $200 \mathrm{Ha}$ dan di Pulau jemur seluas 200 Ha. Sedangkan di Tanah Putih terdapat di Pulau Tilan seluas 410,4 Ha.

Keberadaan Tanah Adat di Rokan Hilir pada masa Kesultanan Siak (1772-1942) pada saat ini keadaannya sudah mengalami krisis. Upaya-upaya untuk menghilangkan keberadaan tanah adat ini sudah mulai ada sejak zaman Kolonial Belanda. Ini dapat dilihat pada kebijakan yang di keluar oleh pemerinah Kolonial maupun produk hukum yang dikeluarkan pada masa pemerintahan Indonesia seperti (1) Agrarische Wet stablat 1870 No 55; (2) Kontrak politik Belanda 1885; (3)Besluit 1915; (4) Undang-Undang No 13 tahun 1948 dan Undang-Undang 1950; (5) UUPA No tahun 1960; dan (6) UU No 5 Tahun 1979. Regulasi hukum yang di keluarkan ini telah memarjinalkan keberadaan tanah adat di Rokan Hilir

Ada kekayaan yang melimpah ruah dalam alam yang harus dieksploitasi demi mengubah kehidupan manusia. Modernisasi menawarkan pola hidup baru yang bertentangan secara diametral dengan pola hidup masyarakat adat Melayu . Hidup selaras dengan alam dalam kesederhanaan alam dikutuk sebagai keterbelakangan yang harus ditinggalkan. Jalan untuk itu adalah mengeksploitasi dan 
mengorbankan alam demi kenikmatan ekonomis manusia yang bersifat pragmatis.Alam harus diubah, demikian pula kehidupan alamiah harus diubah. Manusia tidak boleh lagi bergantung pada alam, melainkan bergantung pada dirinya sendiri dengan kekuatan akal budi dan teknologi dengan menaklukkan dan mengubah alam. Karena manusia tidak lagi bergantung pada alam, seluruh kearifan lokal menjadi tidak penting lagi. Kearifan lokal hanya punya arti ketika hidup manusia bergantung pada dan ditentukan oleh alam, oleh nasib. Dengan mempraktekkan kearifan lokal, masyarakat adat menjamin bahwa alam dan nasib masih memberinya kehidupan. Semua ini hilang ketika dengan pandangan antroposentrik teknologi dan modernisasi manusia bisa menentukan nasib hidupnya.

Dengan demikian, segala pengetahuan tradisional yang bernilai ekonomis tinggi dipertahankan dan ditransformasikan ke dalam pandangan antroposentrik sambil menutup jejak asalnya sama sekali pada kearifan lokal. Bukti paling nyata adalah pengetahuan botani dan penyembuhan tradisional masyarakat maasyarakat adat yang diambil alih dengan sedikit sekali meninggalkan jejak tradisionalnya, seakan merupakan penemuan asli masyarakat ilmiah modern.

Untuk menyelamatkan tankearifan lokal Melayu harus kembali ke nilai-nilai etika sosio-eko-religio-culture secara holistik dan adaptif . Hak-hak masyarakat adat Melayu harus diakui dan dijamin oleh pihak pemerintah. Harus ada komitmen politik di tingkat global dan nasional untuk melindungi hak-hak kearifan lokal . Melalui pendekatan paradigma esosioco-religgio-culture ini untuk menyelamatkan keberadaan local wiisdom Melayu beserta seluruh kekayaan dan kearifan tradisionalnya, melainkan juga menyelamatkan krisis ekologi yang terutama disebabkan oleh kesalahan cara pandang dan perilaku masyarakat yang berparadigma antroposentrik kapitalistik.

Komitmen politik dan moral ke arah itu telah muncul dan disepakati dalam berbagai forum dan oleh berbagai kelompok intemasional. Komitmen politik dan moral ini muncul bersamaan dengan mengemukanya isu lingkungan hidup di satu pihak dan meningkatnya kesadaran mengenai nilai kearifan tradisional di pihak lain. Krisis ekologi sekarang ini tidak saja menimbulkan kritik tajam terhadap paradigma antroposentrik. Krisis ekologi juga menimbulkan kesadaran baru bahwa krisis ekologi bisa diselamatkan dengan kembali kepada kearifan tradisional, etika masyarakat adat. Oleh karena itu, hak-hak tanah adat masyarakat adat harus diakui dandijamin demi menyelamatkan kearifan dan etika masyarakat adat Melayu .

Dalam buku Cultural and Spiritual Values of Biodiversity dapat ditemukan banyak sekali pernyataan atau deklarasi mengenai hakhak masyarakat adat. Hal yang paling menonjol adalah, tuntutan tentang perlindungan atas hakhak masyarakat adat yang merupakan sebuah kecenderungan global yang perlu disambut gembira. Dari fenomena dan observasi lapangan ditemukan lemahnya dasar hukum dan perlindungan politik terhadap hak-hak tanah adat dan masyarakat adat. Di tengah maraknya deklarasi-deklarasi penyelamatan lingkungan ada kecenderungan globalisasi untuk melupakan eksistensi tanah adat masyarakat adat beserta hak-haknya. Sedangkan disisi lain, di tengah upaya pembangunan ekonomi nasional, yang terutama bertumpu pada sumber daya alam,tidak ada implementasi dalam bentuk perlindungan hukum nasional yang signifikan terhadap kearifan lokal Melayu.

Dalam masalah kearifan lokal Melayu, ,misalnya, belum ada langkah politik yang signifikan untuk melindungi secara hukum hakhak kearifan lokal . Padahal masyarakat adat merupakan esensi untuk melindungi dan simbol identitas budaya Melayu. . Dengan kata lain, terjemahan komitmen politik dan moral pada tingkat global ke tingkat nasional masih belum memuaskan. Bahkan, sebagaimana dikatakan oleh Darrell Addison Posey,dalam Keraf (2010) "Banyak negara bahkan tidak mengakui hak-hak dasar suku-suku asli untuk hidup, apalagi menjamin bagi mereka hak untuk menentukan nasib sendiri, hak milik atas tanah adat, atau hak untuk menguasai sumber-sumber daya tradisionainya.Oleh karena itu perlu komitmen dan langkah politik yang signifikan untuk melindungi tanah adat dalam perspektif sosio ecoreligio -culture.

Persolan yang penting disini adalah, perusahaan perusahan raksasa dalam dunia modern menggunakan hukum positif untuk menilai keberadaan masyarakat adat dengan 
seluruh kekayaan dan kearifan tradisionalnya. Ketika masyarakat adat dinilai dalam perspektif hukum positif masyarakat dan negara modern, seluruh hak dan kekayaan yang dimiliki masyarakat adat diekploitasi sewenag wenang dan tidak akan pernah diakui, karena hak-hak masyarakat adat itu tidak ada dalam hukum positif. Hal ini terlihat, tidak ada dasar hukum positif bagi kepemilikan tanah adat dan wilayah masyarakat adat Melayu. Bahkan kearifan lokal Melayu dan seluruh kekayaan alam termasuk keanekaragaman hayati disekitarnya yang dimiliki secara turun temurun oleh masyarakat Melayu tidak diakui secara legal karena tidak diatur dalam hukum positif. Kearifan lokal dan seluruh kekayaan tersebut disebut liar termasuk keanekaragaman hayati: binatang liar dan tanaman liar. Karena dianggap liar, yang berarti bebas dan menjadi milik publik, siapa saja boleh menjarahnya, termasuk masyarakat, negara, dan orang-orang dari luar (bahkan orang asing dalam kaitan dengan biopiracy) (Keraf, 2010). Dengan pendekatan antroposentrik kapitalistik ini ini, segala penjarahan dan pencurian kekayaan masyarakat adat dianggap sah dan dibenarkan, karena tidak ada dasar hukum yang melarangnya, apalagi kekayaan itu dianggap liar Untuk melindungi keberadaan masyarakat Melayu beserta seluruh kekayaan tradisi budayanya, termasuk kearifan tradisionalnya dan dalam rangka untuk melindungi keanekaragaman hayati beberapa hak masyarakat adat berikut ini perlu diakui, dijamin dan dilindungi dengan pendekatan sosio eco-religio culture. Pertama, hak untuk menentukan diri sendiri identitas dan budaya Ini merupakan hak moral dan legal yang melekat pada eksistensi masyarakat Melayu sebagai manusia yang berperadaban. Oleh karena itu, sebagaimana berlaku bagi semua negara bangsa di dunia, hak untuk menentukan diri sendiri harus pula diakui, dijamin dan dilindungi untuk masyarakat adat. Tentu saja ini tidak berarti masyarakat adat Melayu berwatak egosentrik atau chauvinistik. Yang menjadi sasaran utama dari hak ini adalah, masyarakat adat mempunyai posisi legal dan moral yang setara dengan kelompok masyarakat peradaban lainnya untuk didengar dan dilibatkan dalam semua prosespolitik yang menentukan nasib mereka. Masyarakat adat tidak boleh diabaikan, dan nasib mereka tidak boleh ditentukan secara sepihak oleh pihak luar. Demikian pula, seluruh kekayaan mereka termasuk kearifan lokal, dan budaya harus diakui mempunyai status legal, khususnya dalam perspektif hukum kodrat atau hukum adat, sehingga harus diakui pula oleh hukum positif.

Termasuk dalam hak untuk menentukan nasib sendiri adalah hak untuk pindah tempat tinggal, hak untuk mempertahankan atau meninggalkan tradisi budaya, hak untuk meninggalkan atau mempertahankan gaya hidup.Masyarakat adat mempunyai hak penuh untukmelalui mekanisme adat yang mereka milikimenentukan pola pengaturan hidup bersama di dalam kelompoknya, dan untuk menjadi apa saja dalam segala dimensi kehidupannya: ekologis, agama, hukum , ekonomi, budaya, sosial, etik, dan politik.

Kedua, hak teritori lokal wisdom Melayu . Ini penting karena lokal wisdom terkait secara langsung dengan eksistensi mereka. Nilai nilai budaya lokal tidak dapat dipisahkan dari keberadaan mereka beserta seluruh tradisinya. Oleh karena itu, merampas teritori lokal wisdom mereka, atas nama apa saja, merupakan sebuah pengingkaran dan pemusnahan terhadap eksistensi masyarakat adat. Maka, hak atas teritori dan tanah merupakan hak paling fundamental bagi masyarakat adat.

Termasuk di dalam hak atas tanah adat dan teritori ini adalah hak untuk tidak dipindahkan dari tanah leluhurnya, hak untuk menggunakan tanah dan sumber daya alam yang ada di dalam tanah milik mereka, dan hak untuk melindungi tanah milik mereka. Hak-hak ini tidak boleh dirampas dan diambil dari mereka (inalienable rights).

Ketiga, hak asasi kolektif. Ini sebenarnya penegasan kembali bahwa hak-hak asasi yang disepakati secara hokum legal formal harus ada bagi masyarakat ,. Hanya saja, berbeda dengan rezim hak asasi di bawah PBB yang cenderung individualistik, masyarakat adat menuntut agar hak-hak tersebut tidak saja dijamin bagi setiap manusia, melainkan juga bagi kelompok manusia, khususnya kelompok masyarakat adat .. Maka, dalam kaitan dengan hak atas kebebasan, masyarakat adat Melayu menekankan jaminan bagi hak atas kebebasan untuk menjadi dirinya sendiri dengan segala identitas budaya yang unik dalam kelompok 
budayanya. Masyarakat adat menekankan tanggung jawab komunal atas nasib hidup sesamanya dalam kelompok budayanya. Juga termasuk dalam hak atas kebebasan ini adalah, hak kolektif sebagai kelompok untuk hidup denganbebas, aman, damai dan tenteram tanpa intervensi dan kekerasan, khususnya intervensi dan kekerasan militer pada masa Orde Suharto ( 1967-1998).

Keempat, hak budaya. Budaya bagi masyarakat adat Melayu mencakup segalagalanya, termasuk pengetahuan dan kearifan tradisional,berhutan, berdamar, berotan, mengail, melukah, berikan, bertani, berkebun, berburu, menjerat, tarian, nyanyian, bahasa, tempat-tempat keramat, cerita-cerita dongeng, bekoba, inovasi dan praktik-praktik kehidupan dalam kerajinan tradisional, dan sebagainya. Ini adalah kekayaan yang sangat bernilai, bukan sekadar kekayaan fisik melainkan juga kekayaan spiritual dan moral. Oleh karena itu, masyarakat adat Melayu menuntut agar hak mereka untuk mempertahankan dan melestarikan, bahkan mengembangkan, budaya mereka harus diakui dan dijamin. Namun, karena begitu eratnya hubungan antara budaya masyarakat adat dengan alam, melestarikan budaya masyarakat adat berarti pula melestarikan alam di sekitar mereka. Seluruh budaya ini harus diperhitungkan secara serius dalam setiap kebijakan pembangunan yang berdampak pada kelestarian budaya dan ekologis masyarakat adat Melayu .

Untuk itu, perlu ada upaya-upaya khusus, termasuk dari negara, untuk melindungi kekayaan budaya masyarakat adat , termasuk pengetahuan, teknologi, dan segala bentuk manifestasi budaya, serta sumber-sumber genetik, benih, obat-obatan, pengetahuan mengenai ciri-ciri fauna dan flora, tradisi lisan atau dongeng, sastra (khususnya sastra lisan), serta seni pola penataan ruang budaya tradisional. Pemerintah perlu mengambil kebijakan legal-formal-ekocultur untuk melindungi kekayaan budaya agar tidak punah secara alamiah dan tidak dicuri serta dihancurkan oleh intervensi pihak luar, termasuk pihak asing.

Kelima, masyarakat adat Melayu mempunyai hak untuk menganut sistem kepercayaan serta nilai-nilai islami dan akhlak mereka sendiri, yang tidak boleh dilanggar oleh pihak luar. Mereka tidak boleh dipaksa untuk meninggalkan praktik-praktik religius yang mereka miliki turun-temurun. Kebebasan untuk menjalani agama mereka harus dijamin. Demikian pula, tempat-tempat suci serta obyekobyek pemujaan mereka, termasuk binatang dan tumbuhan yang dianggapnya keramat, harus dilindungi dan dijaga keutuhannya. Menjamin hak ini akan mempunyai kontribusi sangat positif bagi pelestarian lingkungan hidup.

Keenam, hak untuk tidak diperlakukan secara diskriminatif the right of nondiscrimination). Ini sebenarnya konsekuensi dari pengakuan akan hak asasi manusia. Dengan ini mau dikatakan bahwa masyarakat adat Melayu mempunyai posisi moral dan hukum yang sama dan sederajat dengan masyarakat dan manusia lain. Oleh karena itu, segala bentuk perlakuan yang diskriminatif terhadap mereka harus dihindari. Negara memang perlu mengembangkan kebijakan paradigmaecoculture khusus bagi mereka, tetapi kebijakan khusus ini lebih dalam kerangka perlindungan atas masyarakat adat dari invasi dan degradasi tradisi budaya mereka, dan bukan dalam pengertian perlakuan yang meminggirkan dan merendahkan martabat mereka.

Ketujuh, masyarakat adat Melayu mempunyai hak untuk ikut berpartisipasi secara penuh dalam proses politik yang menyangkut kepentingan bersama semua kelompok masyarakat. Ini terutama penting dalam kerangka pembangunan yang mempunyai dampak bagi lingkungan hidup di sekitar mereka serta bagi kelestarian tradisi budaya dan eksistensi mereka. Pendekatan politik yang menganggap mereka sekadar obyek yang bisa dipindahkan dan dikorbankan dalam setiap pembangunan antroposentrik sangat tidak etis dan melanggar hak-hak masyarakat adat. Hak atas partisipasi ini tidak semata-mata berbentuk perwakilan mereka dalam lembaga formal seperti Lembaga Legislatif. Yang lebih penting dan menentukan adalah keikutsertaan mereka dalamsetiap proses pengambilan kebijakan, termasuk perumusan peraturan perundangundangan yang secara langsung atau tidak langsung menyangkut kepentingan mereka. Demikian pula, perlu ada mekanisme nyata untuk memungkinkan mereka mendapatkan informasi yang lengkap, akurat dan jujur tentang 
setiap kebijakan publik yang berdampak positif atau negatif pada kepentingan mereka.

Kedelapan, hak untuk memperoleh ganti rugi atas setiap kegiatan yang menimbulkan dampak merugikan bagi lingkungan hidup dan nilai-nilai sosial,fisik, agama, budaya, spiritual dan moral masyarakat adat. Ganti rugi ini harus diatur dalam hukum positif agar masyarakat adat Melayu tidak dirugikan secara ekonomis, dan agar kekayaan serta nilai-nilai ekologis, budaya, sosial, spiritual, dan moral yang mereka miliki tidak punah begitu saja, khususnya oleh invasi pihak luar.

\section{SIMPULAN}

Terjadinya Krisis lingkungan global menyangkut aspek sosial, fisik, ekonomi, agama,politik hukum ,dan budaya masyarakat adat Melayu disebabkan oleh cara pandang yang antroposentrik- kapitalistik . Untuk penyelamatan lingkungan yang berklanjutan perlu merobah cara pandang antroposentrik kapitalistik ke sosio-eco-religio culture yang holistik integrated adaptif dalam perubahan global

\section{UCAPAN TERIMA KASIH}

Pada kesempatan ini penulis mengucapkan terima kasih kepada semua pihak yang membantu dalam melaksanakan penelitian ini. kepada Program Studi Doktor Lingkungan Universitas Riau yang secara intensif telah melibatkan penulis dalam seminar dan lokakarya Nasional Lingkungan demi untuk menghasilkan karya ilmiah yang baik.

\section{DAFTAR PUSTAKA}

Haar, T B,. 1931 Het Adatrecht van Naderlandsch -Indie in Watenschap, Practij en Onderwijs

Keraf, A.S. $2010 \quad$ Etika Lingkungan. Jakarta, Kompas

Vollenhoven, C 1930 Het Adatrecht van Naderlandsch- Indi, Dell III dalam Soerjono Soekonto, Pokok-Pokok Hukum Adat ., Bandung 1984. 